\title{
Synthesis of $\mathrm{PbS}$ nanocrystallites using a novel single molecule precursors approach: $\mathrm{X}$-ray single-crystal structure of $\mathrm{Pb}\left(\mathrm{S}_{2} \mathrm{CNEtPr}{ }^{\mathrm{i}}\right)_{2}$
}

\author{
Tito Trindade, ${ }^{a} \uparrow$ Paul O’Brien, ${ }^{*}{ }^{a}+$ Xiao-mei Zhang $^{b}$ and Majid Motevalli ${ }^{c}$ \\ ${ }^{a}$ Department of Chemistry, Imperial College of Science, Technology and Medicine, London, UK SW7 $2 A Y$ \\ ${ }^{b}$ The Interdisciplinary Research Centre for Semiconductor Materials, The Blackett Laboratory, Imperial College of \\ Science, Technology and Medicine, London, UK SW7 2BZ \\ ${ }^{c}$ Department of Chemistry, Queen Mary \& Westfield College, London, UK E1 4NS
}

\begin{abstract}
The synthesis and characterisation of some lead(II) dithiocarbamato complexes $\mathrm{Pb}\left(\mathrm{S}_{2} \mathrm{CNRR}\right)_{2}$ is reported. These compounds were used as single molecule precursors to produce nanocrystalline $\mathrm{PbS}$ by their thermolysis in trioctylphosphine oxide. The optical and morphological properties of the resulting $\mathrm{PbS}$ nanocrystallites were investigated; the influence of experimental parameters, such as precursor, growth time and temperature, on the final nanodispersed materials is also reported.
\end{abstract}

The last decade has seen intense research into the synthesis and characterisation of semiconductor nanocrystallites. Nanocrystallites have electro-optical and mechanical properties distinct from macrocrystalline materials and are promising materials for several technological applications. ${ }^{1-6}$

Nanocrystalline $\mathrm{PbS}$ is a semiconductor that has received some attention and a number of studies related to the synthesis and optical characterisation of this material can be found in the literature..$^{7-13}$ However, unlike II-VI semiconductors (e.g. $\mathrm{CdS}$ and $\mathrm{CdSe}$ ) which have been prepared by a wide range of synthetic procedures ${ }^{1-6}$ most of the methods employed, to date, for the synthesis of $\mathrm{PbS}$ nanocrystallites are based on traditional precipitation techniques in aqueous media ${ }^{7-9}$ or by crystallisation in structures such as zeolites ${ }^{10}$ or polymers. ${ }^{11-13}$ We report here a novel method for the preparation of nanocrystalline $\mathrm{PbS}$ which uses the thermolysis of single molecule precursors in tri- $n$-octylphosphine oxide (TOPO). A similar method has been used in our laboratories to synthesise $\mathrm{CdS}$ or CdSe nanocrystallites. ${ }^{14}$ High-quality nanocrystallites have been prepared by using TOPO as a dispersing medium either by the single-source ${ }^{14}$ or by the two-precursors approach of Bawendi and co-workers. ${ }^{15}$ Although there is a report on the preparation of bulk $\mathrm{PbS}$ from lead bis(butylthiolate), ${ }^{16}$ to the best of our knowledge the synthesis of nanodispersed $\mathrm{PbS}$ using a single molecule precursor has not been reported before. However, this case is one in which the single-source approach is clearly advantageous because the use of poisonous compounds such as $\mathrm{H}_{2} \mathrm{~S}$ or lead alkyls is avoided.

Lead dithiocarbamato complexes have received little attention as potential precursors for the production of $\mathrm{PbS}$ materials. ${ }^{17}$ In this paper we describe the use of such precursors for the production of $\mathrm{PbS}$ nanocrystallites. The optical and structural properties of the nanoparticulates were evaluated by optical absorption measurements and high-resolution transmission electron microscopy (HRTEM). The influence of experimental parameters on the final properties of the nanocrystallites is also discussed.

\section{Experimental}

\section{Synthesis of lead(II ) dithiocarbamato complexes}

$\mathrm{Pb}\left(\mathrm{NO}_{3}\right)_{2}$, ethanol (99.7-100\%), dichloromethane and $\mathrm{CS}_{2}$ were from BDH. All other chemicals were from Aldrich. TOPO

$\dagger$ Present address: Department of Chemistry, University of Aveiro, 3810 Aveiro, Portugal.

† E-mail: p.obrien@ic.ac.uk
( $90 \%$, Aldrich) was purified by the method described in the literature. ${ }^{18}$ All other chemicals were used as received.

$\mathrm{Pb}\left(\mathrm{S}_{2} \mathrm{CNEt}_{2}\right)_{2}$ was synthesised by the stoichiometric reaction of $0.1 \mathrm{~mol} \mathrm{dm}^{-3}$ aqueous solutions of $\mathrm{Pb}\left(\mathrm{NO}_{3}\right)_{2}(50 \mathrm{ml})$ and $\mathrm{Na}\left(\mathrm{S}_{2} \mathrm{CNEt}_{2}\right)(50 \mathrm{ml})$. The pale yellow precipitate was then washed thoroughly with distilled water and dried at room temperature. All the other lead complexes were synthesised by the insertion of $\mathrm{CS}_{2}$ into the respective secondary amine, in the presence of a suspension of freshly prepared yellow $\mathrm{PbO}$ in ethanol. In a typical synthesis $\mathrm{Pb}\left(\mathrm{S}_{2} \mathrm{CNEtPr}{ }^{\mathrm{i}}\right)_{2}$ was prepared by adding $0.23 \mathrm{~cm}^{3}$ ( $4.13 \mathrm{mmol}$ ) of $\mathrm{CS}_{2}$ to $50 \mathrm{ml}$ of an ethanolic suspension containing $0.5 \mathrm{~cm}^{3}(4.13 \mathrm{mmol})$ of $N$-ethylisopropylamine and $0.5 \mathrm{~g}(2.07 \mathrm{mmol})$ of yellow $\mathrm{PbO}$. The mixture was stirred overnight at room temperature; after addition of $10 \mathrm{ml}$ of $\mathrm{CH}_{2} \mathrm{Cl}_{2}$ to the solution any unreacted $\mathrm{PbO}$ was removed by filtration. The solvent was then evaporated under reduced pressure. Crystals of $\mathrm{Pb}\left(\mathrm{S}_{2} \mathrm{CNEtPr}{ }^{\mathrm{i}}\right)_{2}$ suitable for crystallography were obtained on recrystallisation of the compound in hot toluene $\left(90^{\circ} \mathrm{C}\right)$.

$\mathbf{P b}\left(\mathbf{S}_{\mathbf{2}} \mathbf{C N E t}_{2}\right)_{2} \cdot{ }^{1} \mathrm{H}$ NMR, $\delta 1.33\left(3 \mathrm{H}, \mathrm{t}, \mathrm{CH}_{2} \mathrm{CH}_{3}\right), 3.80(2 \mathrm{H}$, q, $\left.\mathrm{CH}_{2} \mathrm{CH}_{3}\right) ;{ }^{13} \mathrm{C} \mathrm{NMR}, \delta 12.29\left(\mathrm{CH}_{2} \mathrm{CH}_{3}\right), 47.31\left(\mathrm{CH}_{2} \mathrm{CH}_{3}\right)$, 202.17 $\left(\mathrm{S}_{2} \mathrm{CN}\right.$ ); IR and Raman, $v / \mathrm{cm}^{-1}$ (major bands, Raman bands in italic and tentative assignments): 1483, 1489 $[v(\mathrm{C}-\mathrm{N})]$; 983, $987[v(\mathrm{C}-\mathrm{S})] ; 357,362[v(\mathrm{~Pb}-\mathrm{S})]$; yield: $93 \%$.

$\mathbf{P b}\left(\mathbf{S}_{\mathbf{2}} \mathbf{C N E t P r}{ }^{\mathrm{i}}\right)_{2} \cdot{ }^{1} \mathrm{H}$ NMR, $\delta 1.37\left(3 \mathrm{H}, \mathrm{t}, \mathrm{CH}_{2} \mathrm{CH}_{3}\right), 3.72$ $\left(2 \mathrm{H}, \mathrm{q}, \mathrm{CH}_{2} \mathrm{CH}_{3}\right), 1.31\left[6 \mathrm{H}, \mathrm{d}, \mathrm{CH}\left(\mathrm{CH}_{3}\right)_{2}\right], 5.47[1 \mathrm{H}, \mathrm{m}$, $\left.\mathrm{CH}\left(\mathrm{CH}_{3}\right)_{2}\right] ;{ }^{13} \mathrm{C} \mathrm{NMR}, \delta 14.38\left(\mathrm{CH}_{2} \mathrm{CH}_{3}\right), 20.00\left[\mathrm{CH}\left(\mathrm{CH}_{3}\right)_{2}\right]$, $\delta 41.42\left(\mathrm{CH}_{2} \mathrm{CH}_{3}\right), 53.28\left[\mathrm{CH}\left(\mathrm{CH}_{3}\right)_{2}\right], 202.23\left(\mathrm{~S}_{2} \mathrm{CN}\right)$; IR and Raman, $v / \mathrm{cm}^{-1}: 1472,1464[v(\mathrm{C}-\mathrm{N})]$; 987, $986[v(\mathrm{C}-\mathrm{S})]$; $358,374[v(\mathrm{~Pb}-\mathrm{S})]$; yield: $53 \%$.

$\left.\mathbf{P b}\left(\mathbf{S}_{\mathbf{2}} \mathbf{C N M e B u}\right)_{2}\right)^{1} \mathrm{H}$ NMR, $\delta 0.95\left[3 \mathrm{H}, \mathrm{t},\left(\mathrm{CH}_{2}\right)_{3} \mathrm{CH}_{3}\right]$, $1.36 \quad\left[2 \mathrm{H}, \quad \mathrm{m}, \quad\left(\mathrm{CH}_{2}\right)_{2} \mathrm{CH}_{2} \mathrm{CH}_{3}\right], \quad \delta \quad 1.73 \quad(2 \mathrm{H}, \quad \mathrm{m}$, $\left.\mathrm{CH}_{2} \mathrm{CH}_{2} \mathrm{CH}_{2} \mathrm{CH}_{3}\right), 3.32\left(3 \mathrm{H}, \quad \mathrm{s}, \mathrm{CH}_{3}\right), 3.76 \quad[2 \mathrm{H}, \mathrm{t}$, $\left.\mathrm{CH}_{2}\left(\mathrm{CH}_{2}\right)_{2} \mathrm{CH}_{3}\right] ;{ }^{13} \mathrm{C}$ NMR, $\delta 13.83 \quad\left[\left(\mathrm{CH}_{2}\right)_{3} \mathrm{CH}_{3}\right], 20.13$ $\left[\left(\mathrm{CH}_{2}\right)_{2} \mathrm{CH}_{2} \mathrm{CH}_{3}\right], 29.02\left(\mathrm{CH}_{2} \mathrm{CH}_{2} \mathrm{CH}_{2} \mathrm{CH}_{3}\right), 40.78\left(\mathrm{CH}_{3}\right), \delta$ $55.19\left[\mathrm{CH}_{2}\left(\mathrm{CH}_{2}\right)_{2} \mathrm{CH}_{3}\right], 203.15\left(\mathrm{~S}_{2} \mathrm{CN}\right)$; IR and Raman, $v / \mathrm{cm}^{-1}: 1491,1490[v(\mathrm{C}-\mathrm{N}] ; 960,960[v(\mathrm{C}-\mathrm{S})], 357,358$ $[v(\mathrm{~Pb}-\mathrm{S}]$; yield: $58 \%$.

$\mathbf{P b}\left(\mathbf{S}_{\mathbf{2}} \mathbf{C N B u}^{\mathbf{n}}{ }_{2}\right)_{2} \cdot{ }^{1} \mathrm{H}$ NMR, $\delta 0.95\left[3 \mathrm{H}, \mathrm{t},\left(\mathrm{CH}_{2}\right)_{3} \mathrm{CH}_{3}\right], 1.35$ $\left[2 \mathrm{H}, \mathrm{m},\left(\mathrm{CH}_{2}\right)_{2} \mathrm{CH}_{2} \mathrm{CH}_{3}\right], 1.75\left(2 \mathrm{H}, \mathrm{m}, \mathrm{CH}_{2} \mathrm{CH}_{2} \mathrm{CH}_{2} \mathrm{CH}_{3}\right)$, $3.70\left[2 \mathrm{H}, \mathrm{t}, \mathrm{CH}_{2}\left(\mathrm{CH}_{2}\right)_{2} \mathrm{CH}_{3}\right] ;{ }^{13} \mathrm{C} \mathrm{NMR}, \delta 13.77\left[\left(\mathrm{CH}_{2}\right)_{3} \mathrm{CH}_{3}\right]$, 
Table 1 Properties of some $\mathrm{Pb}\left(\mathrm{S}_{2} \mathrm{CNRR}^{\prime}\right)_{2}$ complexes

\begin{tabular}{|c|c|c|c|c|c|c|c|c|}
\hline \multirow[b]{2}{*}{ compound } & \multirow[b]{2}{*}{$\mathrm{R}$} & \multirow[b]{2}{*}{$\mathrm{R}^{\prime}$} & \multirow[b]{2}{*}{ colour } & \multirow[b]{2}{*}{$\mathrm{mp} /{ }^{\circ} \mathrm{C}$} & \multicolumn{3}{|c|}{$\operatorname{analysis}^{a}(\%)$} & \multirow[b]{2}{*}{$m / z^{b}$} \\
\hline & & & & & $\mathrm{C}$ & $\mathrm{H}$ & $\mathrm{N}$ & \\
\hline $\mathrm{Pb}\left(\mathrm{S}_{2} \mathrm{CNEt}_{2}\right)_{2}$ & Et & $\mathrm{Et}$ & pale yellow & 208 & $\begin{array}{c}23.7 \\
(23.8)\end{array}$ & $\begin{array}{l}3.8 \\
(4.0)\end{array}$ & $\begin{array}{l}5.5 \\
(5.6)\end{array}$ & $\begin{array}{l}356 \\
\left\{\mathrm{PbS}_{2} \mathrm{CNEt}_{2}\right\}^{+}\end{array}$ \\
\hline $\mathrm{Pb}\left(\mathrm{S}_{2} \mathrm{CNEtPr}{ }^{\mathrm{i}}\right)_{2}$ & $\mathrm{Et}$ & $\operatorname{Pr}^{\mathrm{i}}$ & pale yellow & 127 & $\begin{array}{c}27.1 \\
(27.3)\end{array}$ & $\begin{array}{c}4.2 \\
(3.8)\end{array}$ & $\begin{array}{l}5.3 \\
(5.3)\end{array}$ & $\begin{array}{l}370 \\
\left\{\mathrm{PbS}_{2} \mathrm{CNEtPr}^{\mathrm{i}}\right\}^{+}\end{array}$ \\
\hline $\mathrm{Pb}\left(\mathrm{S}_{2} \mathrm{CNMeBu^{ \textrm {n } }}\right)_{2}$ & $\mathrm{Me}$ & $\mathrm{Bu}^{\mathrm{n}}$ & white & 98 & $\begin{array}{c}27.2 \\
(27.1)\end{array}$ & $\begin{array}{c}4.5 \\
(4.6)\end{array}$ & $\begin{array}{l}5.2 \\
(5.3)\end{array}$ & $\begin{array}{l}370 \\
\left\{\mathrm{PbS}_{2} \mathrm{CNMeBu}^{\mathrm{n}}\right\}^{+}\end{array}$ \\
\hline $\mathrm{Pb}\left(\mathrm{S}_{2} \mathrm{CNBu}_{2}{ }_{2}\right)_{2}$ & $\mathrm{Bu}^{\mathrm{n}}$ & $\mathrm{Bu}^{\mathrm{n}}$ & pale yellow & 76 & $\begin{array}{c}35.1 \\
(35.1)\end{array}$ & $\begin{array}{l}5.6 \\
(5.9)\end{array}$ & $\begin{array}{l}4.5 \\
(4.6)\end{array}$ & $\left\{\mathrm{PbS}_{2} \mathrm{CNBu}_{2}^{\mathrm{t}}\right\}^{+}$ \\
\hline $\mathrm{Pb}\left(\mathrm{S}_{2} \mathrm{CNBu}_{2}^{\mathrm{i}}\right)_{2}$ & $\mathrm{Bu}^{\mathrm{i}}$ & $\mathrm{Bu}^{\mathrm{i}}$ & pale yellow & 98 & $\begin{array}{c}34.0 \\
(35.1)\end{array}$ & $\begin{array}{c}5.1 \\
(5.9)\end{array}$ & $\begin{array}{c}4.5 \\
(4.6)\end{array}$ & $\left\{\mathrm{PbS}_{2} \mathrm{CNBu}_{2}^{\mathrm{i}}\right\}^{+}$ \\
\hline $\mathrm{Pb}\left[\mathrm{S}_{2} \mathrm{CNMe}\left(n-\mathrm{C}_{6} \mathrm{H}_{13}\right)\right]_{2}$ & $\mathrm{Me}$ & $n-\mathrm{C}_{6} \mathrm{H}_{13}$ & pale yellow & 87 & $\begin{array}{c}33.9 \\
(32.7)\end{array}$ & $\begin{array}{l}5.8 \\
(5.5)\end{array}$ & $\begin{array}{c}5.1 \\
(4.8)\end{array}$ & $\left\{\mathrm{PbS}_{2} \mathrm{CNMe}\left(n-\mathrm{C}_{6} \mathrm{H}_{13}\right)\right\}^{+}$ \\
\hline
\end{tabular}

${ }^{a}$ Calculated values in parentheses. ${ }^{b}$ Strongest peak in the mass spectrum.

$20.23\left[\left(\mathrm{CH}_{2}\right)_{2} \mathrm{CH}_{2} \mathrm{CH}_{3}\right], 29.06 \quad\left(\mathrm{CH}_{2} \mathrm{CH}_{2} \mathrm{CH}_{2} \mathrm{CH}_{3}\right), \quad 52.92$ $\left[\mathrm{CH}_{2}\left(\mathrm{CH}_{2}\right)_{2} \mathrm{CH}_{3}\right], 202.49\left(\mathrm{~S}_{2} \mathrm{CN}\right) ; \mathrm{IR}$ and Raman, $v / \mathrm{cm}^{-1}$ : $1478,1477[v(\mathrm{C}-\mathrm{N})]$; 961, $961[v(\mathrm{C}-\mathrm{S})] ; 359,372[v(\mathrm{~Pb}-\mathrm{S})]$; yield: $56 \%$.

$\mathbf{P b}\left(\mathbf{S}_{\mathbf{2}} \mathbf{C N B u}{ }_{2}\right)_{2} \cdot{ }^{1} \mathrm{H}$ NMR, $\delta 0.95\left[6 \mathrm{H}, \mathrm{d},\left(\mathrm{CH}_{2} \mathrm{CH}\left(\mathrm{CH}_{3}\right)_{2}\right]\right.$, $2.46\left[1 \mathrm{H}, \mathrm{m}, \mathrm{CH}_{2} \mathrm{CH}\left(\mathrm{CH}_{3}\right)_{2}\right], 3.62\left[2 \mathrm{H}, \mathrm{d}, \mathrm{CH}_{2} \mathrm{CH}\left(\mathrm{CH}_{3}\right)_{2}\right]$; ${ }^{13} \mathrm{C} \mathrm{NMR,} \delta 20.37\left[\mathrm{CH}_{2} \mathrm{CH}\left(\mathrm{CH}_{3}\right)_{2}\right], 27.07\left[\mathrm{CH}_{2} \mathrm{CH}\left(\mathrm{CH}_{3}\right)_{2}\right]$, $60.64\left[\mathrm{CH}_{2} \mathrm{CH}\left(\mathrm{CH}_{3}\right)_{2}\right], 204.55\left(\mathrm{~S}_{2} \mathrm{CN}\right)$; IR and Raman, $v / \mathrm{cm}^{-1}: 1475,1479[v(\mathrm{C}-\mathrm{N})] ; 972,960[v(\mathrm{C}-\mathrm{S})] ; 341,369$ $[v(\mathrm{~Pb}-\mathrm{S})]$; yield: $46 \%$.

$\mathbf{P b}\left[\mathrm{S}_{\mathbf{2}} \mathbf{C N M e}\left(\boldsymbol{n}-\mathbf{C}_{\mathbf{6}} \mathbf{H}_{13}\right)\right]_{2} . \quad{ }^{1} \mathrm{H} \quad \mathrm{NMR}, \quad 0.89 \quad[3 \mathrm{H}, \quad \mathrm{t}$, $\left.\left(\mathrm{CH}_{2}\right)_{5} \mathrm{CH}_{3}\right], 1.30\left[6 \mathrm{H}, \mathrm{m},\left(\mathrm{CH}_{2}\right)_{2}\left(\mathrm{CH}_{2}\right)_{3} \mathrm{CH}_{3}\right], 1.74[2 \mathrm{H}, \mathrm{m}$, $\left.\mathrm{CH}_{2} \mathrm{CH}_{2}\left(\mathrm{CH}_{2}\right)_{3} \mathrm{CH}_{3}\right], 3.32\left(3 \mathrm{H}, \mathrm{s}, \mathrm{CH}_{3}\right), \delta 3.75[2 \mathrm{H}, \mathrm{t}$, $\left.\mathrm{CH}_{2}\left(\mathrm{CH}_{2}\right)_{4} \mathrm{CH}_{3}\right] ;{ }^{13} \mathrm{C}$ NMR, $\delta 14.05\left[\left(\mathrm{CH}_{2}\right)_{5} \mathrm{CH}_{3}\right], 22.58$ $\left[\left(\mathrm{CH}_{2}\right)_{4} \mathrm{CH}_{2} \mathrm{CH}_{3}\right], \quad 26.51 \quad\left[\left(\mathrm{CH}_{2}\right)_{3} \mathrm{CH}_{2} \mathrm{CH}_{2} \mathrm{CH}_{3}\right], \quad 26.87$ $\left[\left(\mathrm{CH}_{2}\right)_{2} \mathrm{CH}_{2}\left(\mathrm{CH}_{2}\right)_{2} \mathrm{CH}_{3}\right], 31.49\left[\mathrm{CH}_{2} \mathrm{CH}_{2}\left(\mathrm{CH}_{2}\right)_{3} \mathrm{CH}_{3}\right], 40.82$ $\left(\mathrm{CH}_{3}\right), 55.45\left[\mathrm{CH}_{2}\left(\mathrm{CH}_{2}\right)_{4} \mathrm{CH}_{3}\right], 202.98\left(\mathrm{~S}_{2} \mathrm{CN}\right) ; \mathrm{IR}$ and Raman, $v / \mathrm{cm}^{-1}: 1491,1488[v(\mathrm{C}-\mathrm{N})] ;$ 964, $968[v(\mathrm{C}-\mathrm{S})] ; 357,360$ $[v(\mathrm{~Pb}-\mathrm{S})]$; yield: $76 \%$.

Table 1 lists other properties for the above complexes. Microanalysis was carried out in the Microanalytical Laboratories at Imperial College.

\section{Synthesis of $\mathrm{PbS}$ nanocrystallites}

The $\mathrm{PbS}$ nanocrystallites were synthesised by injecting solutions of $\mathrm{Pb}\left(\mathrm{S}_{2} \mathrm{CNRR}^{\prime}\right)_{2}$ [in toluene or trioctylphosphine (TOP)] into TOPO at a required temperature $\left(\right.$ e.g. $\left.150^{\circ} \mathrm{C}\right)$ under an atmosphere of nitrogen.

In a typical preparation, $\mathrm{Pb}\left(\mathrm{S}_{2} \mathrm{CNBu}_{2}^{\mathrm{i}}\right)_{2} \quad(0.12 \mathrm{mmol}$, $0.075 \mathrm{~g}$ ) was dissolved in $5 \mathrm{ml}$ of toluene. This solution was carefully injected into $30 \mathrm{~g}$ of TOPO, while stirring at 100-150 ${ }^{\circ} \mathrm{C}$ (CAUTION: at normal pressure the boiling point of toluene is $111^{\circ} \mathrm{C}$ ). The reaction vessel, a three-necked tubular flask, was connected via a lateral neck to a flask equipped with a Liebig condenser in order to remove any toluene from the reactant solution. After heating (e.g. for $1 \mathrm{~h}$ ) the grey mixture was allowed to cool to $70{ }^{\circ} \mathrm{C}$ and an excess of $\mathrm{MeOH}$ was added. The solid was then isolated by centrifugation, washed with $\mathrm{MeOH}(10 \mathrm{ml})$ and dried under vacuum. The synthesis of $\mathrm{PbS}$ nanocrystallites at 200 and $250{ }^{\circ} \mathrm{C}$ was carried out by injecting the precursor at $150^{\circ} \mathrm{C}$ and then slowly increasing the temperature. TOP could be used instead of toluene but a loss of the solubility of the precursor was observed.

The formation of nanocrystallites with heating time was monitored by recording the optical absorption spectra of aliquots $(2 \mathrm{ml})$ collected with a syringe from the reactant solution, addition of an excess of $\mathrm{MeOH}$, centrifugation and redispersion in toluene.

The synthesis of $\mathrm{PbS}$ nanocrystallites using other molecular precursors was carried out using similar synthetic procedures.

\section{Instrumentation and physical measurements}

Crystallography. Intensity data were collected on an EnrafNonius CAD-4 diffractometer operating in the $\omega-2 \theta$ scan mode, with graphite-monochromated Mo-K $\alpha$ radiation. The unit-cell parameters were determined by least-squares refinements on positions of 25 automatically centred reflections with $10 \leqslant \theta \leqslant 14^{\circ}$. The structures were solved by the direct method using the SHELX program package ${ }^{19}$ and refined anisotropically on $F^{2}$ by full-matrix least-squares procedures using the SHELXL-93 package. ${ }^{20}$ The crystal data and structure refinement data for $\mathrm{Pb}\left(\mathrm{S}_{2} \mathrm{CNEtPr}{ }^{\mathrm{i}}\right)_{2}$ are shown in Table 2. All $\mathrm{H}$ atoms were placed at calculated positions by using AFIX command in SHELXL-93 (riding model). Displacement parameters of $\mathrm{H}$ atoms were kept fixed at the isotropic values of the parent atoms. Atomic coordinates, thermal parameters, and bond lengths and angles have been deposited at the Cambridge Crystallographic Data Centre (CCDC). See

Table 2 Crystal data and structure refinement of $\mathrm{Pb}\left(\mathrm{S}_{2} \mathrm{CNEtPr}{ }^{\mathrm{i}}\right)_{2}$

\begin{tabular}{|c|c|}
\hline empirical formula & $\mathrm{C}_{12} \mathrm{H}_{24} \mathrm{~N}_{2} \mathrm{PbS}_{4}$ \\
\hline formula mass & 531.76 \\
\hline temperature/K & $293(2)$ \\
\hline wavelength/A & 0.71069 \\
\hline crystal system & monoclinic \\
\hline space group & $C / c$ \\
\hline \multicolumn{2}{|l|}{ unit-cell dimensions } \\
\hline$a / \AA$ & $22.478(4)$ \\
\hline$b / \AA$ & $9.718(2)$ \\
\hline$c / \AA$ & $8.734(2)$ \\
\hline$\beta /$ degrees & $102.62(3)$ \\
\hline volume $/ \AA^{3}$ & $1861.8(7)$ \\
\hline$Z$ & 4 \\
\hline$D_{\mathrm{c}} / \mathrm{g} \mathrm{cm}^{-3}$ & 1.897 \\
\hline absorption coefficient $/ \mathrm{mm}^{-1}$ & 9.501 \\
\hline$F(100)$ & 1024 \\
\hline crystal size $/ \mathrm{mm}^{3}$ & $0.45 \times 0.25 \times 0.13$ \\
\hline \multicolumn{2}{|c|}{$\theta$ range for data collection/degrees $1.86-24.97$} \\
\hline index range $h k l$ & -26 to $26,-5$ to $11,-10$ to 3 \\
\hline reflections collected & 1818 \\
\hline independent reflections $\left(R_{\text {int }}\right)$ & $1771(0.0122)$ \\
\hline refinement method & full-matrix least-squares on $F^{2}$ \\
\hline data/restraints/parameters & $1770 / 2 / 189$ \\
\hline goodness-of-fit on $F^{2}$ & 1.096 \\
\hline final $R$ indices $[I>2 \sigma(I)]$ & $R_{1}=0.0289, w R_{2}=0.0717$ \\
\hline \multicolumn{2}{|c|}{$R$ indices (all data) $\quad R_{1}=0.0446, w R_{2}=0.0752$} \\
\hline largest difference peak, hole/e & $0.885,-0.839$ \\
\hline
\end{tabular}




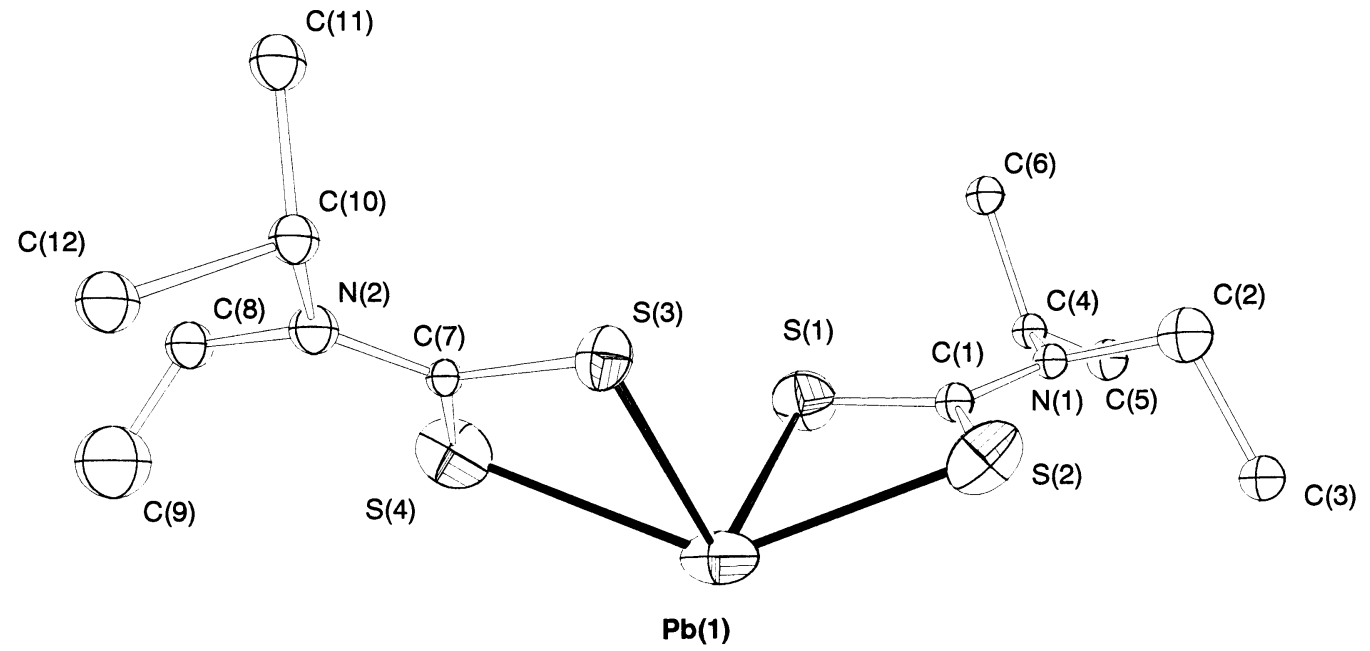

Fig. 1 X-Ray single-crystal structure of $\mathrm{Pb}\left(\mathrm{S}_{2} \mathrm{CNEtPr}\right)_{2}$

Information for Authors, J. Mater. Chem., 1997, Issue 1. Any request to the CCDC for this material should quote the full literature citation and the reference number 1145/35.

Spectroscopic measurements. ${ }^{1} \mathrm{H}$ NMR and ${ }^{13} \mathrm{C}\left\{{ }^{1} \mathrm{H}\right\} \mathrm{NMR}$ spectra were recorded on a JEOL ESX 270 or on a Brüker WM-250 FT using $\mathrm{CDCl}_{3}-\mathrm{SiMe}_{4}$ as solvent. IR spectra were recorded on a Matson instrument using CsI disks. Raman spectra were measured as powders on a Perkin-Elmer 1760X FTIR instrument fitted with a 1700X NIR FT-Raman accessory (Spectron Nd: YAG laser, $1064 \mathrm{~nm}$ excitation). Mass spectra were recorded on a VG Autospec, using for positive FAB a $\mathrm{Cs}^{+}$primary ion beam $(30 \mathrm{keV})$ and using a 3-nitrobenzyl alcohol matrix.

Electron microscopy and electron diffraction. HRTEM images and transmission electron diffraction patterns were obtained using a JEOL-JEM-2010 electron microscope operating at $200 \mathrm{kV}$. Samples were prepared by placing an aliquot of a toluene solution containing $\mathrm{PbS}$ nanocrystallites onto a carbon-coated copper grid and then allowing the solvent to evaporate at room temperature. Measurements of the dimensions of the nanoparticles were performed directly using the HRTEM images. In order to index the electron diffraction patterns, the camera constant was determined using an aluminium standard.

\section{Results and Discussion}

\section{Single molecule precursors}

There are a few papers reporting the synthesis and thermal behaviour of lead(II) dithiocarbamates. ${ }^{21-24}$ The X-ray singlecrystal structures of $\mathrm{Pb}\left(\mathrm{S}_{2} \mathrm{CNR}_{2}\right)_{2}, \mathrm{R}=\mathrm{Me},{ }^{25} \mathrm{Et}^{26,27}$ and $\mathrm{Pr}^{\mathrm{i}} 28$ have been reported. These compounds, however, are far from being fully characterised.

The crystal structure of $\mathrm{Pb}\left(\mathrm{S}_{2} \mathrm{CNEtPr}{ }^{\mathrm{i}}\right)_{2}$ is shown in Fig. 1 . This compound has two different alkyl substituents on the nitrogen but has a crystal structure core similar to those of $\mathrm{Pb}\left(\mathrm{S}_{2} \mathrm{CNMe}_{2}\right)_{2}, \mathrm{~Pb}\left(\mathrm{~S}_{2} \mathrm{CNEt}_{2}\right)_{2}$ and $\mathrm{Pb}\left(\mathrm{S}_{2} \mathrm{CNPr}_{2}{ }_{2}\right)_{2}$, which were reported previously. ${ }^{25-28}$ The lead atom is coordinated to four sulfur atoms, two from each ethylisopropyldithiocarbamato chelating ligand. The total number of sulfur atoms surrounding each lead atom is six if short intermolecular contacts, with two different neighbouring molecules are considered (Fig. 2, Table 3). The intermolecular distances $\mathrm{Pb}(1) \cdots \mathrm{S}^{\prime}(1)[3.488(2) \AA]$ and $\mathrm{Pb}(1) \cdots \mathrm{S}\left(3^{\prime}\right)$ [3.497(2) $\AA$ ] are longer than a covalent $\mathrm{Pb}-\mathrm{S}$ bond but shorter than the sum

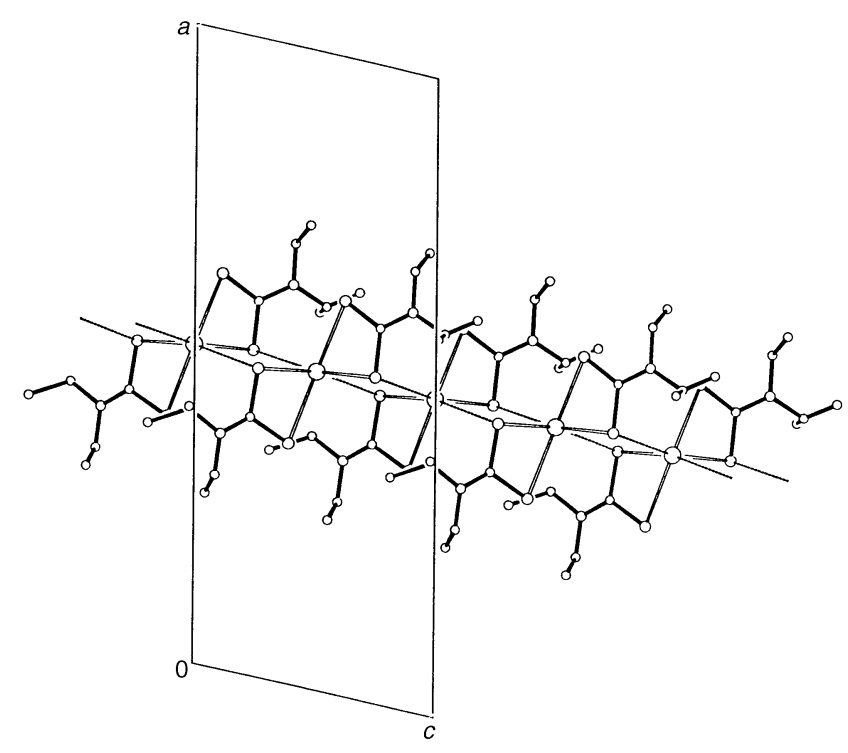

Fig. 2 Molecular packing diagram of $\mathrm{Pb}\left(\mathrm{S}_{2} \mathrm{CNEtPr}{ }^{\mathrm{i}}\right)_{2}$

Table 3 Selected bond lengths ( $\AA$ ) and angles (degrees) for $\mathrm{Pb}\left(\mathrm{S}_{2} \mathrm{CNEtPr}{ }^{\mathrm{i}}\right)_{2}$

\begin{tabular}{lllr}
$\mathrm{Pb}(1)-\mathrm{S}(3)$ & $2.675(2)$ & $\mathrm{S}(3)-\mathrm{Pb}(1)-\mathrm{S}(1)$ & $99.11(4)$ \\
$\mathrm{Pb}(1)-\mathrm{S}(1)$ & $2.714(2)$ & $\mathrm{S}(3)-\mathrm{Pb}(1)-\mathrm{S}(2)$ & $89.32(7)$ \\
$\mathrm{Pb}(1)-\mathrm{S}(2)$ & $2.862(3)$ & $\mathrm{S}(1)-\mathrm{Pb}(1)-\mathrm{S}(2)$ & $64.36(6)$ \\
$\mathrm{Pb}(1)-\mathrm{S}(4)$ & $2.880(3)$ & $\mathrm{S}(3)-\mathrm{Pb}(1)-\mathrm{S}(4)$ & $63.78(7)$ \\
$\mathrm{Pb}(1) \cdots \mathrm{S}^{\prime}(1)$ & $3.488(2)$ & $\mathrm{S}(1)-\mathrm{Pb}(1)-\mathrm{S}(4)$ & $88.24(6)$ \\
$\mathrm{Pb}(1) \cdots \mathrm{S}^{\prime}(1)$ & $3.497(2)$ & $\mathrm{S}(2)-\mathrm{Pb}(1)-\mathrm{S}(4)$ & $138.60(5)$ \\
\hline
\end{tabular}

of van der Waals radii $(3.82 \AA) .{ }^{29}$ This type of environment is similar to that one observed for the lead atom in $\mathrm{Pb}\left(\mathrm{S}_{2} \mathrm{CNPr}{ }_{2}\right)_{2},{ }^{28}$ for $\mathrm{Pb}\left(\mathrm{S}_{2} \mathrm{CNEt}_{2}\right)_{2}$ two of the six sulfur atoms surrounding the metal atom (and forming intermolecular contacts) belong to the same neighbouring molecule. ${ }^{27}$ Fig. 2 shows that the molecular units of $\mathrm{Pb}\left(\mathrm{S}_{2} \mathrm{CNEtPr}{ }_{2}^{\mathrm{i}}\right)_{2}$ are aligned along the $c$ axis, similar to $\mathrm{Pb}\left(\mathrm{S}_{2} \mathrm{CNEt}_{2}\right)_{2}{ }^{26,27}$ and $\mathrm{Pb}\left(\mathrm{S}_{2} \mathrm{CNMe}{ }_{2}\right)_{2},{ }^{25}$ and in contrast to $\mathrm{Pb}\left(\mathrm{S}_{2} \mathrm{CNPr}{ }_{2}^{\mathrm{i}}\right)_{2}$ in which a linear-chain structure along the $b$ axis is formed. ${ }^{28}$ The four $\mathrm{Pb}-\mathrm{S}$ distances in the compound $\mathrm{Pb}\left(\mathrm{S}_{2} \mathrm{CNEtPr}\right)_{2}$ (Table 3) are different and the sulfur atoms are non-coplanar. The relative bond distances and bond angles (Table 3 ) for $\mathrm{Pb}\left(\mathrm{S}_{2} \mathrm{CNEtPr}{ }^{\mathrm{i}}\right)_{2}$ agree with the presence of an electron lone 
pair (E) at an equatorial position of a distorted trigonalbipyramid $\mathrm{PbS}_{4} \mathrm{E}$. Evidence for the presence of a stereochemically active electron lone pair at the lead atom has also been reported for other lead complexes. ${ }^{30,31}$

The vibrational data showed the characteristic bands for the compounds. The strong bands in the region $1460-1500 \mathrm{~cm}^{-1}$ were assigned to the stretching of the $\mathrm{C}-\mathrm{N}$ bond, which has polar characteristics and is intermediate between a single and double bond. In the region of the $\mathrm{C}-\mathrm{S}$ stretching vibration, $960-1000 \mathrm{~cm}^{-1}$, only a strong band was found in the vibrational spectra for the dithiocarbamato complexes, which is expected if the bidentate ligands are chelated to the lead atom and do not have a free $\mathrm{C}-\mathrm{S}$ bond. ${ }^{32} \mathrm{The} \mathrm{Pb}-\mathrm{S}$ stretching vibration was assigned to the IR and Raman bands found in the low-frequency region $300-380 \mathrm{~cm}^{-1}$. These bands were generally weak in the IR and of medium intensity in the Raman spectra. Xanthate, dithiooxalate and dithiocarbamate complexes show the metal-sulfur stretching mode at $288-436 \mathrm{~cm}^{-1} \cdot{ }^{33-35}$ The assignment of $v(\mathrm{~Pb}-\mathrm{S})$ to the stronger bands observed in this spectral region was made on that basis, ${ }^{33}$ although the same authors have reported ${ }^{34}$ that $v(\mathrm{~Pb}-\mathrm{S})$ can be low as $170 \mathrm{~cm}^{-1}$ in lead thiourea complexes, containing the non-charged thiourea ligand.

A decrease in the melting point of the compounds was observed as the alkyl groups become longer or/and asymmetrical. Similar behaviour has been observed for zinc and cadmium dithiocarbamato complexes, ${ }^{36,37}$ and may be explained by an increase of the steric hindrance of the ligand, weakening the intermolecular forces within the compounds.

\section{Optical properties of $\mathrm{PbS}$ nanocrystallites}

$\mathrm{The} \mathrm{Pb}\left(\mathrm{S}_{2} \mathrm{CNRR}^{\prime}\right)_{2}$ complexes when dispersed in hot TOPO decomposed to give a brown-grey material. After injection of the precursor into hot TOPO $\left(\right.$ e.g. $\left.150^{\circ} \mathrm{C}\right)$ the solution changed in a matter of 10-30 min from pale yellow to brownish-grey and, over longer times, to black. Fig. 3 shows the optical absorption spectra of nanodispersed $\mathrm{PbS}$ in toluene obtained from the thermolysis of different $\mathrm{Pb}\left(\mathrm{S}_{2} \mathrm{CNRR}^{\prime}\right)_{2}$ precursors in TOPO. The optical properties of the $\mathrm{PbS}$ suspensions prepared are similar from all precursors (Fig. 3), if other experimental conditions remain constant. It was found that the temperature of injection, and growth time, have much more effect on the optical absorption spectra of nanodispersed $\mathrm{PbS}$ than the nature of the precursors used (Fig. 4). Using the same precursor, e.g. $\mathrm{Pb}\left(\mathrm{S}_{2} \mathrm{CNBu}_{2}{ }_{2}\right)_{2}$, the absorption tail steepens for $\mathrm{PbS}$ synthesised at $100{ }^{\circ} \mathrm{C}$ as compared to $150^{\circ} \mathrm{C}$. A similar result was observed for samples prepared for shorter heating times (Fig. 5). The optical spectra for all the samples of $\mathrm{PbS}$ analysed, independent of the synthetic conditions used, were featureless and a smooth decrease in the optical absorption from the near

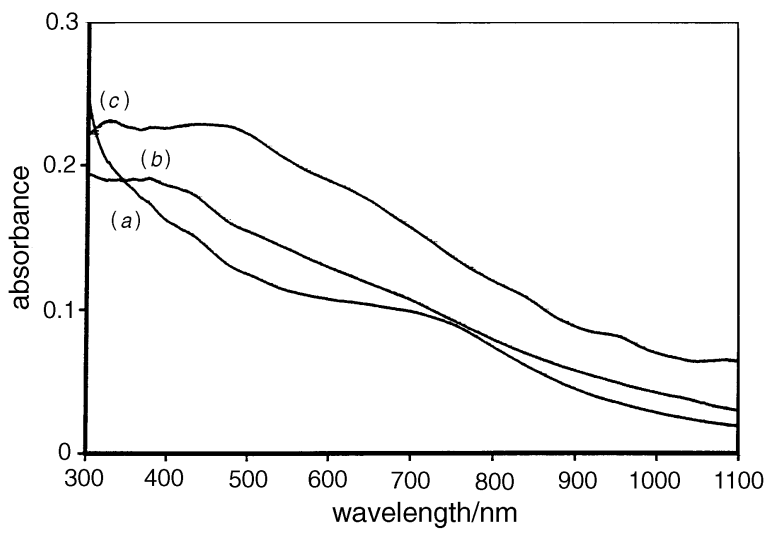

Fig. 3 Optical absorption spectra of nanodispersed $\mathrm{PbS}$ in toluene, synthesised in TOPO at $150{ }^{\circ} \mathrm{C}$ from $\mathrm{Pb}\left(\mathrm{S}_{2} \mathrm{CNRR}^{\prime}\right)_{2}$ over $1 \mathrm{~h}$ : (a) $\mathrm{R}=\mathrm{R}^{\prime}=\mathrm{Bu}^{\mathrm{n}} ;$ (b) $\mathrm{R}=\mathrm{Me}, \mathrm{R}^{\prime}=n-\mathrm{C}_{6} \mathrm{H}_{13} ;$ (c) $\mathrm{R}=\mathrm{R}^{\prime}=\mathrm{Bu}^{\mathrm{i}}$

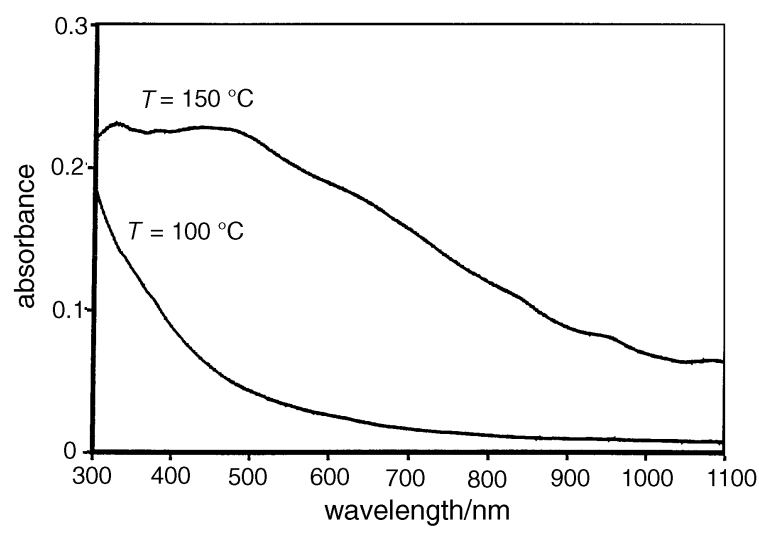

Fig. 4 Optical absorption spectra of nanodispersed $\mathrm{PbS}$ in toluene, synthesised from $\mathrm{Pb}\left(\mathrm{S}_{2} \mathrm{CNBu}_{2}^{\mathrm{i}}\right)_{2}$ in TOPO at 100 and $150{ }^{\circ} \mathrm{C}$, over $1 \mathrm{~h}$

UV to the NIR $(1100 \mathrm{~nm})$ was always observed. Although a sharp edge was not observed in any of the optical spectra, Fig. 3-5 suggest that the $\mathrm{PbS}$ particles should have diameters in the nanometre range. The direct optical band-gap of macrocrystalline $\mathrm{PbS}$ is $c a$. $0.4 \mathrm{eV}(3100 \mathrm{~nm})$; absorption of light from this wavelength to higher energy, forming a continuum, occurs in bulk PbS. This is not the case for nanodispersed $\mathrm{PbS}$ described here, as shown in Fig. 3-5.

A blue shift in the absorbance band should occur for $\mathrm{PbS}$ nanoparticles of large size $(>20 \mathrm{~nm})$ as compared to semiconductors such as II-VI materials. For example, CdS shows a three-dimensional quantum confinement for particles smaller than $60 \AA$. However because the bulk exciton radius of $\mathrm{PbS}$ is larger than for $\mathrm{CdS}$ the former shows quantum size effects for nanoparticles up to $160 \AA$ in diameter. Although quantum confined semiconductors, such as CdS and CdSe, usually show excitonic features in their optical spectra, for $\mathrm{PbS}$ this effect has not been observed so often. Well defined absorption features were reported for molecular-like PbS clusters $(<13 \AA)$ prepared in a polymeric matrix ${ }^{11}$ and for $\mathrm{PbS}$ synthesised in the presence of poly(vinyl alcohol) in methanolic or aqueous solutions. ${ }^{9}$

\section{Morphological and structural properties of PbS nanocrystallites}

The PbS nanocrystallites have the cubic (rock-salt type) structure. The transmission electron diffraction pattern of a typical sample showed rings which were indexed to the $d$-spacings of cubic $\mathrm{PbS}$ [Fig. 6(b)]. Fig. 6(a) shows the diffraction pattern of a single nanocrystal in which the $\{200\}$ and $\{220\}$ planes were easily assigned.

The HRTEM images of PbS showed crystalline particles

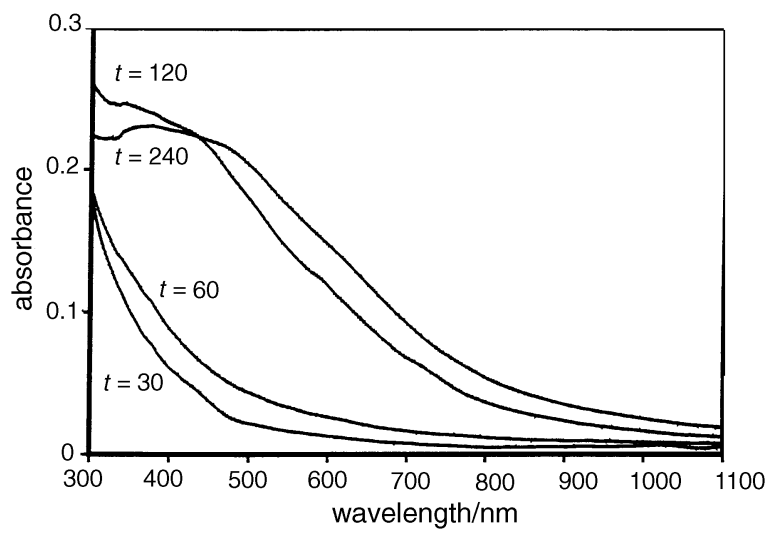

Fig. 5 Optical absorption spectra of nanodispersed $\mathrm{PbS}$, in toluene, synthesised from the thermolysis $\left(100^{\circ} \mathrm{C}\right)$ of $\mathrm{Pb}\left(\mathrm{S}_{2} \mathrm{CNBu}_{2}{ }_{2}\right)_{2}$ in TOPO for different heating times (in minutes) 


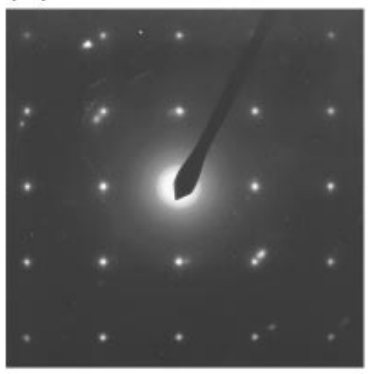

\section{(b)}

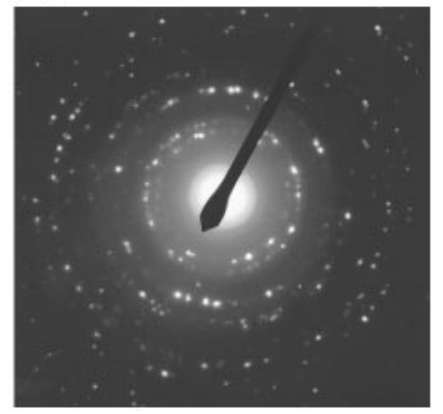

Fig. 6 Transmission electron diffraction patterns of PbS nanocrystallites: (a) single nanocrystal; (b) set of particles

(a)

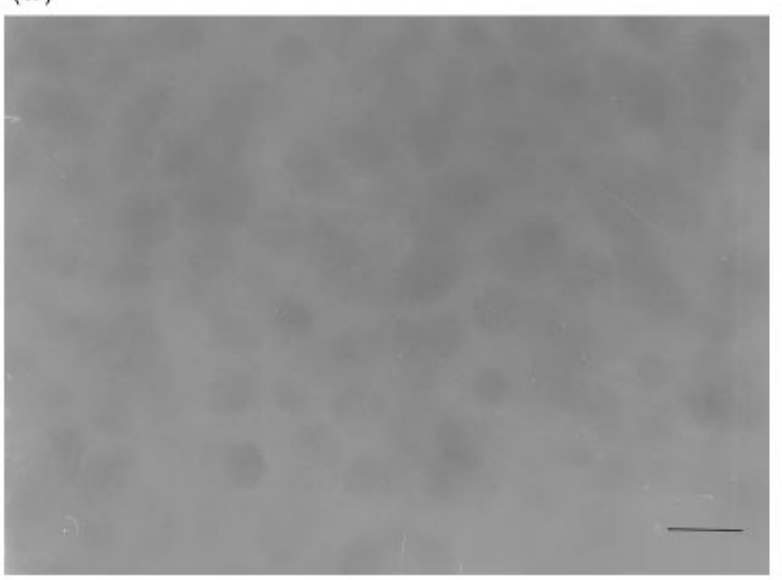

(b)

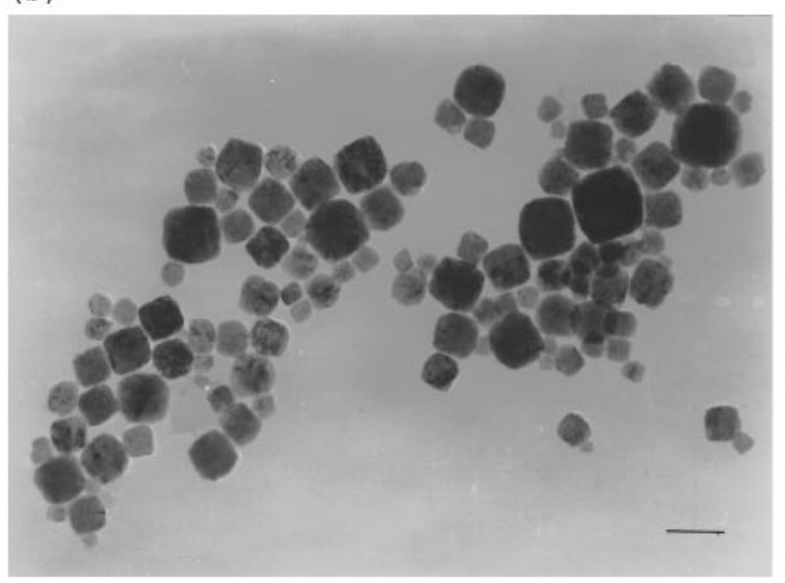

Fig. 7 HRTEM images of $\mathrm{PbS}$ nanocrystallites prepared from thermolysis of $\mathrm{Pb}\left(\mathrm{S}_{2} \mathrm{CNBu}{ }_{2}^{\mathrm{i}}\right)_{2}$ in TOPO, over $1 \mathrm{~h}$, at: (a) $100^{\circ} \mathrm{C}$ $($ bar $=10 \mathrm{~nm})$ and $(b) 150{ }^{\circ} \mathrm{C}($ bar $=100 \mathrm{~nm})$

which were mostly nanosized (Fig. 7). It appears that the temperature at which the $\mathrm{PbS}$ crystals were prepared had a strong influence on their morphology. Fig. 7 shows $\mathrm{PbS}$ nanocrystallites prepared at $100^{\circ} \mathrm{C}(a)$ and $150{ }^{\circ} \mathrm{C}(b)$, respectively. Closer examination of these crystallites show that not only the morphology, but also the size dispersions differ between the two samples. Most of the crystallites prepared at $100{ }^{\circ} \mathrm{C}$ were round in shape and in the quantum size regime $(d=$ $6.3 \pm 1.4 \mathrm{~nm}$ ) for $\mathrm{PbS}$. The size dispersion of the $100^{\circ} \mathrm{C}$ sample was $c a .22 \%$. In the sample prepared at $150{ }^{\circ} \mathrm{C}$, on the other hand, in addition to small rounded nanocrystals, a large number of larger and square shaped nanocrystals were also observed, their average size being of the order $d=85 \pm 23 \mathrm{~nm}$ (measured diagonal of the square). The size dispersion in this

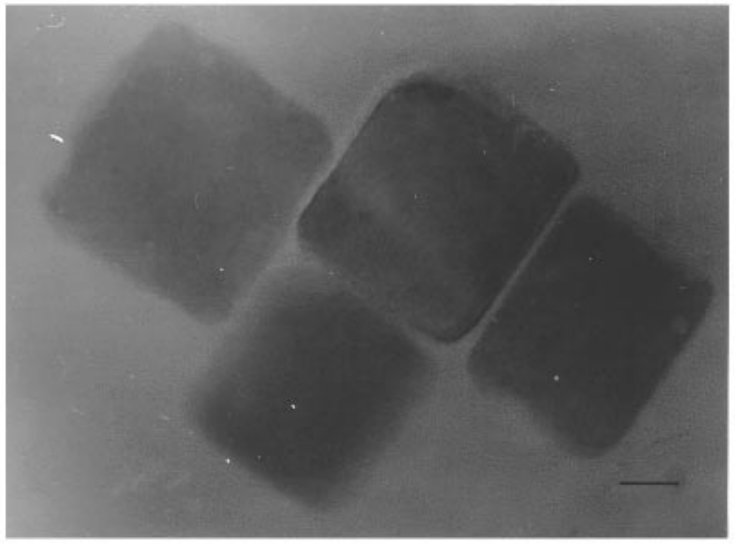

Fig. 8 HRTEM image of PbS nanocrystallites prepared from thermolysis of $\mathrm{Pb}\left(\mathrm{S}_{2} \mathrm{CNEt}_{2}\right)_{2}$ in TOPO, over $1 \mathrm{~h}$, at $250^{\circ} \mathrm{C}(\mathrm{bar}=100 \mathrm{~nm})$

sample was increased to $27 \%$. The size dispersions of both samples were somewhat broader as compared to $\mathrm{CdS}$ or $\mathrm{CdSe}$ nanocrystallites prepared under similar conditions. ${ }^{14}$

The observed morphology of the $\mathrm{PbS}$ crystallites was in accord with the optical measurements which indicated that the crystallites were smaller in the sample prepared at $100{ }^{\circ} \mathrm{C}$ as compared to preparation at $150^{\circ} \mathrm{C}$. The large size dispersion in the $\mathrm{PbS}$ samples could be the reason for the lack of well defined features in the corresponding optical spectra.

Fig. 8 shows a HRTEM image of PbS crystallites grown in TOPO after thermolysis $\left(250^{\circ} \mathrm{C}\right)$ of the precursor $\mathrm{Pb}\left(\mathrm{S}_{2} \mathrm{CNEt}_{2}\right)_{2}$. Two types of morphology were present; most of the crystallites were square while the remainder were hexagonal. On average, the crystallites of the latter group were much larger. This observation suggests that growth of $\mathrm{PbS}$ crystallites at $250^{\circ} \mathrm{C}$ leads to a very broad size distribution. The corresponding optical spectrum of this sample showed strong light scattering close to the longest wavelength reached by the instrument $(1100 \mathrm{~nm})$. These samples were unstable towards agglomeration over a few minutes.

In summary, we have presented a novel and simple method for the preparation of nanodispersed $\mathrm{PbS}$. The optical and morphological properties of the $\mathrm{PbS}$ nanocrystallites are strongly dependent on the temperature of synthesis and less so on the chemical nature of the precursor. However, it should be emphasised that only lead(II) dithiocarbamato complexes were studied. The synthetic method can be easily modified for other types of molecular precursors to $\mathrm{PbS}$.

T. T. acknowledges JNICT (Praxis XXI program) for a grant and P. O'B. thanks the EPSRC for support of quantum dot research at ICTMS.

\section{References}

1 A. Henglein, Chem. Rev., 1989, 89, 1861.

2 M. L. Steigerwald and L. E. Brus, Acc. Chem. Res., 1990, 23, 183.

3 H. Weller, Adv. Mater., 1993, 5, 88 .

4 A. Hagfeldt and M. Grätzel, Chem. Rev., 1995, 95, 49

5 J. H. Fendler and F. C. Meldrun, Adv. Mater., 1995, 7, 607.

6 A. P. Alivisatos, J. Phys. Chem., 1996, 100, 13226.

7 A. J. Nozik, F. Williams, M. T. Nenadovic, T. Rajh and O. I. Micic, J. Phys. Chem., 1985, 89, 397.

8 T. K. Leodidou, W. Caseri and U. W. Suter, J. Phys. Chem., 1994, 98, 8992 .

9 S. Gallardo, M. Gutierrez, A. Henglein and E. Janata, Ber. BunsenGes. Phys. Chem., 1989, 93, 1080.

10 Y. Wang and N. Herron, J. Phys. Chem., 1991, 95, 525.

11 Y. Wang, A. Suna, W. Mahler and R. Kasowski, J. Chem. Phys., $1987,87,7315$

12 R. Tassoni and R. R. Schrock, Chem. Mater., 1994, 6, 744.

13 M. Moffitt and A. Eisenberg, Chem. Mater., 1995, 7, 1178.

14 T. Trindade and P. O'Brien, Adv. Mater., 1996, 8, 161. 
15 C. B. Murray, D. J. Norris and M. G. Bawendi, J. Am. Chem. Soc., 1993, 115, 8706 .

16 G. Kräuter, P. Favreau and W. S. Rees, Jr., Chem. Mater., 1994, 6, 543 .

17 T. Trindade and P. O'Brien, Adv. Mater., in press.

18 R. A. Zingaro and J. C. White, J. Inorg. Nucl. Chem., 1960, 12, 315.

19 G. M. Sheldrick, SHELX, a program for crystal structure solution, University of Göttingen, 1986.

20 G. M. Sheldrick, SHELXL-93, program for crystal structure solution, University of Göttingen, 1993.

21 M. A. Bernard and M. M. Borel, Bull. Soc. Chim. Fr., 1969, 9, 3064.

2 M. A. Bernard and M. M. Borel, Bull. Soc. Chim. Fr., 1969, 9, 1966.

F. Bonati and G. Minghetti, Chim. Ind. (Milan), 1970, 52, 1204.

24 L. A. Kosareva and S. V. Larionov, Izv. Sib. Otd. Akad. Nauk SSSR, Ser. Khim. Nauk, 1989, 4, 33.

25 H. Iwasaki, Acta Crystallogr., Sect. B, 1980, 36, 2138.

26 Z. V. Zvonkova, A. N. Khvatkina and N. S. Ivanova Kristallografiya, 1967, 12, 1065.
27 H. Iwasaki and H. Hagihara, Acta Crystallogr., Sect. B, 1972, 28, 507.

28 M. Ito and H. Iwasaki, Acta Crystallogr., Sect. B, 1980, 36, 443.

29 A. J. Bondi, J. Phys. Chem., 1964, 68, 441.

30 S. L. Lawton and G. T. Kokotailo, Inorg. Chem., 1972, 11, 363.

31 H. U. Hummel, E. Fischer, T. Fischer, D. Gruß, A. Franke and W. Dietzsch, Chem. Ber., 1992, 125, 1565.

32 F. Bonati and R. Ugo, J. Organomet. Chem., 1967, 10, 257.

33 D. M. Adams and J. B. Cornell, J. Chem. Soc. A, 1968, 1299.

34 D. M. Adams and J. B. Cornell, J. Chem. Soc. A, 1967, 884.

35 T. Y. Koh, PhD Thesis, University of London, 1994.

36 M. Motevalli, P. O'Brien, J. R. Walsh and I. M. Watson, Polyhedron, 1996, 15, 2801.

37 P. O'Brien, J. R. Walsh, I. M. Watson, M. Motevalli and L. Henriksen, J. Chem. Soc., Dalton Trans., 1996, 2491.

Paper 6/08579B; Received 23rd December, 1996 